\title{
Science Academies' 82nd Refresher Course on Experimental Physics
}

\author{
6-21, December 2016 \\ Department of Physics, Kakatiya University, Warangal \\ Sponsored by Indian Academy of Sciences, Bengaluru, \\ Indian National Science Academy, New Delhi \\ The National Academy of Sciences India, Allahabad
}

\begin{abstract}
A Refresher Course in Experimental Physics will be held at Department of Physics, Kakatiya University, Warangal from 6 to 21 December 2016 for the benefit of faculty involved in teaching undergraduate and postgraduate courses. The Course aims to familiarize the participants to gain hands on experience with set of new experiments developed as a low cost kit by the Indian Academy of Sciences, Bangalore, Indian National Science Academy, New Delhi and National Academy of Sciences, India, Allahabad and manufactured by Ajay Sensors and Instruments in Bangalore. Prof. R. Srinivasan, a distinguished Physicist, who has devised these experiments for the benefit of teachers and students in Indian Universities, has designed this course. Refresher courses in Experimental Physics held so far have been highly successful and the experiments have been included in 125 institutions including universities, autonomous colleges, and advanced scientific institutions involved in education. UGC has approved two-week Refresher Courses of good standing for promotion, vide notification. F3-1/2009 dated 30 June 2010.
\end{abstract}

Applications are invited from teachers with experience in teaching undergraduate and postgraduate courses in Engineering and Physics. Motivated students of B.Sc. final year and M.Sc. Physics courses with keen interest in Experimental Physics may also apply. The number of seats will be about 35 .

Selected participants will be paid actual fare by bus/train to and fro from their place of work not exceeding Three Tier AC railway fares. Out station participants will be provided boarding and lodging during the Course in addition to course material. Applications should be submitted ONLINE by clicking the following link. http://webjapps.ias.ac.in:8080/Refreshcourse/RCEPW.jsp

A copy of the application form signed by the applicant should also be sent by post to The Course Coordinator. In case of teachers, the form must also be signed and stamped by the Head of the applicant's Institution stating that leave will be sanctioned if the applicant is selected for the Course. A recommendation letter from a teacher is essential for student applicants. Scanned copies of the duly signed documents sent by e-mail will also be accepted.

Applications may be sent to: Prof. A.S. Nageshwar Rao, Course Coordinator, Refresher Course in Experimental Physics, Department of Physics, Kakatiya University, Warangal, Telangana State-506009. e-mail:sarcep@gmail.com, Phone: 0870-2461428, Mobile: 9849531084.

\section{Last date for the receipt of applications: October 31, 2016}

Selected participants will be informed by Email of their selection by: November 10, 2016

For any other query, applicants can send an Email to: sarcep2016@gmail.com. 